\title{
A PEDAGÓgUSOK TARTALMI ÉS MÓDSZERTANI TUDÁSÁNAK FEJLESZTÉSE A KLÍMAVÁLTOZÁSHOZ KAPCSOLÓDVA
}

\section{MiKA JánOS}

\author{
az Eszterházy Károly főiskola \\ egyetemi tanára \\ mikaj@ektf.hu
}

\begin{abstract}
Az éghajlatváltozás az oktatás számára is kihívást jelent, hiszen meg kell ismertetnünk az oktatásban résztvevőkkel, hogy mi a folyamat lényege, mik a következményei, és mit tehetünk a változás lefékezéséért. Írásunk első fele e kérdésekröl szól, míg a második részben arra mutatunk példákat, hogy miként tudjuk kihasználni a klimaváltozás iránti érdeklödést arra, hogy más fontos kérdésekre hívjuk fel a figyelmet és fejlesszünk bizonyos kulcskompetenciákat.
\end{abstract}

\section{Bevezetés}

A környezet a jelen és a jövő generációk alapvető életfeltétele. Ennek minősége meghatározza az emberek élettartamát, az élet minőségét, sőt megfigyelhető, hogy a viselkedésünk, egymáshoz való viszonyunk is más egy rendezett egészséges környezetben, mint amikor a zaj, a szennyeződés, a rendezetlen táj és a szemét közvetlenül hat az érzékeinkre. S akkor még nem szóltunk a globális környezeti változásokkal összefüggésben minden pontban és tevékenységben megnyilvánuló lassú hatásokról, sem azokról, amelyek a levegö, a víz és a talaj szennyezettsége okán észrevétlenül mérgeznek bennünket, vagy éppen a növényi és állati táplálékkal vesszük magunkhoz anélkül, hogy annak veszélyeiröl tudomásunk lenne. Pedig kutatási adatok bizonyítják, hogy sok évben kifejezhető az a fájdalmas élettartamcsökkenés, amit a városainkban még mindig nagyfokú légszennyezettség okoz mind Európában, mind hazánkban.

Amióta környezetünk minden alrendszerében tapasztaljuk a romlást, ráébredtünk, hogy a környezet voltaképpen érték is, amit védenünk kell. De védeni csak azt tudjuk, amit ismerünk. A környezet védelmének első lépése tehát a megismerés, ami tipikus része az egész életen át tartó tanulásnak is. Hiszen lépten-nyomon új problémákkal találkozunk, amelyek nyomán a részrendszerek közötti új összefüggésekre derül fény. Így az élő és az élettelen természet megismerése, amit érdemes tanárként és szülőként segítenünk, már a tanítványok kisgyermek korában megkezdhető. Később egyre tudatosabban a védelem kerülhet a tanulmányok homlok- 
terébe, majd a felsőoktatásban már az alkotó alkalmazás, illetve a pedagógusképzésben ezeknek a szempontoknak a továbbadása lesz a fő feladat.

Tanulmányunkban e tágabb feladat sort a környezetet talán leginkább fenyegető, mindenképpen legismertebb kihívás, az éghajlatváltozás témakörén keresztül közelítjük meg. Írásunk első része arról szól, hogy mit lenne jó megtanítanunk magáról a klímaváltozásról, a második részben pedig rámutatunk azokra a lehetőségekre, amelyek a klímaváltozás apropóján, az e témakör iránti érdeklődés által felerősítve juttatnak el ismereteket, és fejlesztenek kulcskompetenciákat a tanulók körében. A tanárkollégák mindezt akkor tudják elérni, ha felkészültnek érzik magukat ebben a gyorsan fejlődő, bővülő ismeretkörben.

\section{A klímaváltozás oktatása}

\section{A klímaváltozásról dióhéjban}

Földünk éghajlata sosem volt szigorúan állandó, ám a változások az emberi tevékenység megjelenése óta mintegy két nagyságrenddel gyorsabbak a természetes változásoknál. A 19. századtól kezdve, fokozatosan gyorsuló ütemben zajló globális melegedés a 20. század kezdetétől napjainkig megközelíti a 0,8 Celsius fokot, állapítja meg az ENSZ Kormányközi Éghajlatváltozási Testülete, az IPCC (2007).

A klímaváltozás a természetre és az emberre nézve egyaránt fenyegetö következményekkel járhat. Ennek következményeihez egyrészt alkalmazkodnunk kell, másrészt mérsékelnünk, majd minél előbb, azaz minél alacsonyabb átlaghőmérsékleten meg kell állítanunk bolygónk melegedését. Mindezt egyértelmüen szükségessé teszi az IPCC Negyedik Értékelö Jelentése (IPCC, 2007), amelynek fö megállapításai a következők:

- Az éghajlat egy irányban változik.

- Az emberiség ennek legalább részben az okozója.

- Az éghajlat biztosan folytatja az eddigi melegedést.

- Több éghajlati kockázat kisebb melegedésnél is fellép, mint azt korábban számítottuk.

- A kibocsátás mérséklése és az alkalmazkodás együtt csökkenthetik a károkat.

- Kevés időnk maradt arra, hogy az éghajlatot legfeljebb $2{ }^{\circ} \mathrm{C}$ melegedéssel stabilizáljuk.

- Már ma ismert a mérséklés és az alkalmazkodás számos technikai megoldása.

Ma már nincs olyan tudományos fórum, amelyik tagadná, hogy Földünk hosszú évtizedek óta melegszik. És olyan sem sok van, amelyik szerint ennek nem az ember az okozója. Olyan pedig, amelyik ezt valóban bizonyítani is tudná, egy sincsen! 
Ugyanakkor egyre több hír utal arra, hogy a Béke Nobel Díjas ENSZ testület nemrég még vészjóslónak aposztrofált 2007-es jelentése még alul is becsülte az üvegházhatás erősödésének azóta is folytatódó ütemét, amit átmenetileg megszakított ugyan a gazdasági világválság miatt a 2009-es év, de már látszik, hogy 2010 után a folyamat folytatódik.

A 2010-es év mindesetre - egyedül vagy holtversenyben - Bolygónk legmelegebb éve volt a mérések kezdete óta. Tudós kutatók kimutatták, hogy a tengerszint emelkedése 2000 óta az előrejelzett sáv tetején halad. Csak az utóbbi két évtizedben egynegyedével erősödött az üvegházgázok melegítő hatása, s ezt olyan visszacsatolások is erősítettek, mint az örök fagy területének a felmelegedéssel járó olvadása, a jeges talajba zárt metántartalmú anyagok felszabadulása, az óceánok szén-dioxid elnyelö képességének csökkenése a felmelegedés miatt hidrosztatikai értelemben stabilabbá váló, azaz kevésbé átkeveredő óceánok és a bioszféra szén-dioxid megkötésének gyengülése miatt. Ez utóbbi folyamat oka a klímaváltozás folytán kedvezőtlen, új körülmények közé kerülő növényzeti övek termőképességének csökkenése.

Mi európaiak büszkék lehetünk a gazdaságunkra, hiszen az Unió nyolc százalékra vállalt csökkentése, amit a Kiotói Jegyzökönyv (1997) szerint 2010-re kellett megvalósítani, már 2005-re ténnyé vált, még ha nem is csak a környezet védelme okán. De azzal is büszkélkedhet Európa, hogy az összes gazdasági körzet közül messze a legkevesebb üvegház-gázt használja fel egy dollárnyi termék előállításához. Alig 60\%-át annak, amit az USA és Kanada, és jóval kevesebbet, mint a kedvezőbb éghajlatú Japán.

A következőkben röviden bemutatjuk a klímaváltozás legfontosabb tényeit, illetve a ma fennálló tudományos konszenzus tartalmát, amit a diákjainknak is át kell adnunk. Segítheti az érdeklődés fenntartását, ha ezt ellentétek szembeállításával végezzük. Az alábbiakat az IPCC (2007) ábráival tudjuk igazolni, ám tanulmányunk jellege e téren önmegtartóztatásra int.

Jó hir: Bolygónk ötmilliárd éves történetében az éghajlat sokkal nagyobb eltéréseket mutatott, mint amekkora változástól a jövőben tartanunk kell.

Rossz hír: A mostani változás 10-100-szor gyorsabb, mint a természetes változások.

A változás felgyorsulásáért és irányváltásáért elsősorban a légkörben megnövekedett mennyiségü üvegházgáz koncentráció a felelős. Ezek a gázok beengedik a Nap látható sugarait, de a felszínről és a felhőkről kiinduló, a láthatónál hosszabb, $\mathrm{s}$ emiatt nem látható hullámok egy részét viszont elnyelik és visszasugározzák a felszín irányában.

Jó hir: Az üvegházgázok felszaporodása miatt energiatöbblet eddig csupán 1\%-a annak az összes energiának, ami a Naptól a légkörbe és a felszínre jut és ott az időjárási folyamatokat irányítja. Ennek kb. 2/3-át a széndioxid $\left(\mathrm{CO}_{2}\right), 1 / 3$-át pe- 
dig más üvegházgázok, azaz a metán $\left(\mathrm{CH}_{4}\right)$, a dinitrogén-oxid $\left(\mathrm{N}_{2} \mathrm{O}\right)$ és a halogénezett szénhidrogének (freonok, halonok) okozták.

Rossz hir: A XXI. század végére ez a változás a 2-4-szeresére nőhet.

A múlt éghajlatának változását a Földön többé-kevésbé egyenletesen elhelyezett mérőállomások adatai igazolják. A jövőt azonban csak a fizika (részben a kémia és a biológia) törvényszerüségeit felhasználó, számítógépes modellekkel próbáljuk elörebecsülni.

Jó hir: A modellek jóságát bizonyítja, hogy jól „hátrajelzik” a múlt alakulását (1. ábra)

Rossz hir: Ugyanitt látható, hogy csak akkor sikeres a szimuláció, ha figyelembe vesszük az emberi eredetü hatásokat is. Vagyis, igen valószínü (90\%), hogy legalább az utóbbi 50 év melegedését valóban az emberi tevékenység okozta. Csak akkor lehet ebben tévedés, ha az említett modellek évtizedek óta túl nagy hatást számolnak és ugyanakkor valami ismeretlen hatás okozza a változást. Ennek a két hibának együttes valószínüsége kisebb mint $10 \%$.

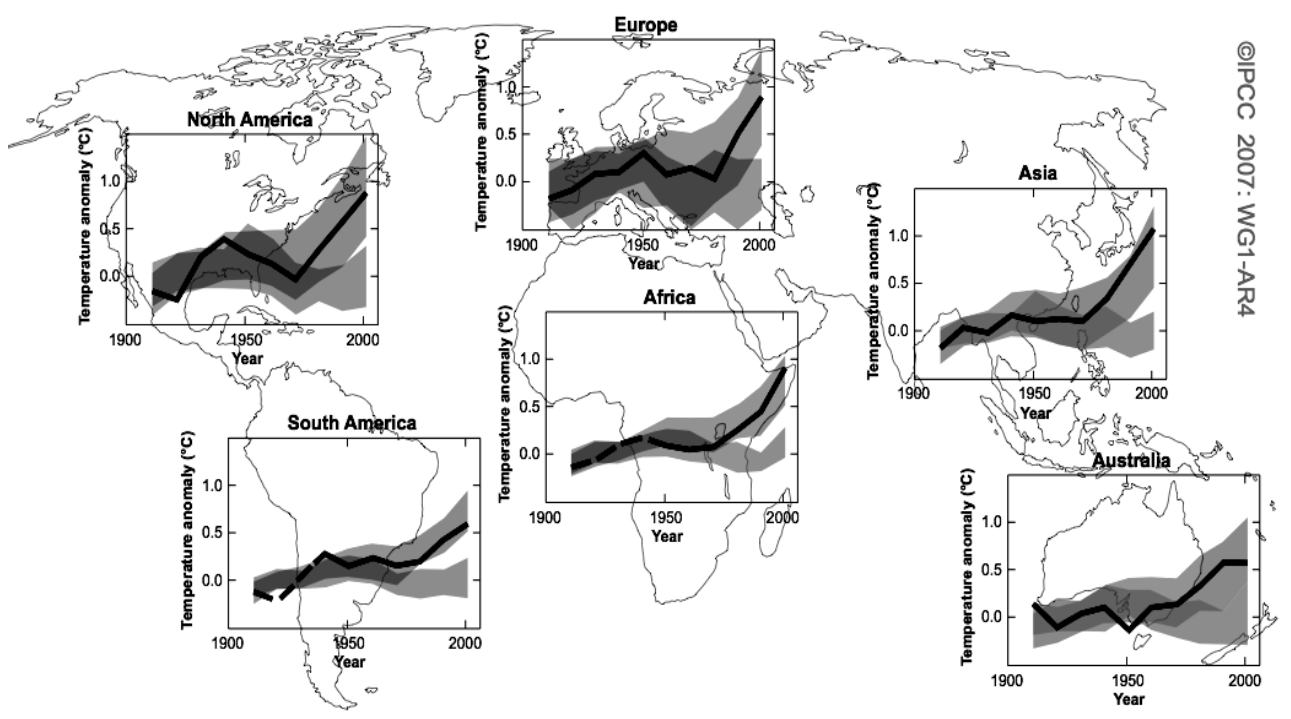

1. ábra: A hőmérséklet „hátrajelzése” klímamodellekben, az ismert természetes és emberi eredetủ hatások alapján. A szimuláció felső sávja (több modell) tartalmazza a megfigyelt értéket (fekete vonal). Ha csak a természetes hatásokat (naptevékenység, vulkánok) vennénk figyelembe (alsó sáv),

akkor az utóbbi fél évszázad melegedése nem magyarázható! (IPCC, 2007)

Az elmúlt évtizedek éghajlatának számítógépes „hátrajelzéséhez” szükség van a légkör egy további jellemzőjének, a légkör szilárd és folyékony alkotórészeinek, az 
ún. aeroszol-részecskéknek az ismeretére. Ezek a részecskék visszafelé is szórják a Nap sugarait, emellett egyes összetevőik növelik a felhők vízmennyiségét, s annak több kisebb méretủ cseppre osztásával fokozzák a felhők fényvisszaverő képességét. Mindkét folyamat hüti bolygónkat, ezért az aeroszol-koncentráció növekedését „,anti-üvegházhatásnak” is nevezik.

Jó hír: Az aeroszolok az elmúlt évszázadokban kb. annyival hütötték bolygónkat, mint amennyivel a széndioxidon felüli, további üvegházhatású gázok melegítették azt.

Rossz hir: Azonban, a müholdas megfigyelések szerint kb. 1990 óta földi átlagban tisztul a légkör, ami azóta tovább erősíti a felmelegedést.

Az elmúlt évtizedek éghajlatának sikeres reprodukálásán felbátorodva a kutatók előrejelzéseket is készítenek, leggyakrabban a Föld átlaghőmérsékletének alakulására vonatkozóan. Az ilyen előrejelzések a népesség, a gazdaságfejlődés, a globalizáció, a környezeti szempontok stb. különböző feltételezései mellett 2100-ig számítják ki a változásokat (2. ábra).

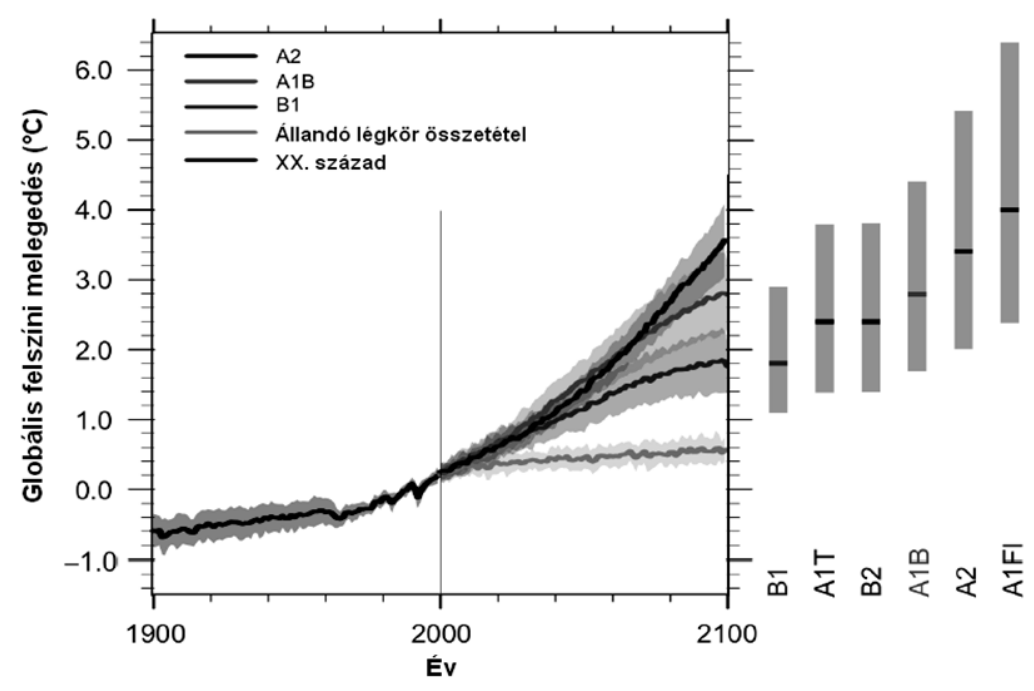

2. ábra: A földi átlaghőmérséklet elörejelzése 2100-ig,

különböző kibocsátási forgatókönyvek alapján. A jobb oldali sávok a klímamodellek közötti eltéréseket érzékeltetik. Ezek alapján a melegedés 1,1 és $6,4^{\circ} \mathrm{C}$ közé esik, minden bizonytalanságot figyelembe véve. A laposan emelkedő vonal a korábbi évtizedek kibocsátása miatti, „büntető” melegedés. (IPCC, 2007)

Korábban azzal is számoltak a kutatók (Broecker, 1991), a katonai stratégák (Schwartz és Randall, 2003) és a filmrendezők („Holnapután”, 2004. május), hogy a melege- 
dés egy későbbi pontján a változás hirtelen lehülésbe, ,jégkorszakba” csap át. Ennek alapja az a lehetőség, hogy az ún. óceáni szállítószalag legyengül, és nem szállít elegendő hőt az északi hideg területekre. Ez a hiányzó hő a feltételezés szerint különösen az Atlanti óceánban hiányozhat és vezethet a jégtakaró kiterjedéséhez, amit a jéghátságokban bezárt, ott olvadó víz kitörése felgyorsíthat. A szállítószalag lassulásának lehetőségét az északi tengerek só-koncentrációjának csökkenése és a klímamodellek is közvetve valószínúsítik.

Jó hír: Ha teljesen leállna is az óceáni szállítószalag, a klímamodellek szerint annak sem jégkorszak lenne a következménye, hanem egy ennél kisebb mértékü, más földrajzi eloszlású lehűlés. Sőt, ha a kísérletben a leállás okát, az üvegházhatás erősödését is figyelembe vesszük, akkor a közvetlenül érintett területeken kívül mindenütt a melegedés lesz az erösebb (Wood et al., 2003).

Rossz hir: Ez az éghajlat azonban így is nagyon különbözne az eddig megszokottól, amihez gazdaságunk és életmódunk alkalmazkodott. A kontinensek és az óceánok közötti erős hőmérsékletkülönbség miatt például megszaporodnának a ciklonok Európában.

Rossz hir: Ha nem is vár jégkorszak Földünkre, a féktelen felmelegedésnek több olyan minőségi változás lehet a következménye. Ilyen változás elsősorban a nyugat-antarktiszi jégtömb megolvadása, ami jelenleg nyugszik a kontinentális talapzaton. Ha azonban a melegedés eléri a kb. $3{ }^{\circ} \mathrm{C}$-ot, akkor a tömb leválik a talapzatról és az Egyenlítő felé sodródva előbb-utóbb elolvad, ami 5 méterrel emelheti a Világtenger szintjét. A Grönlandon felhalmozott jég megolvadása 7 méterrel emelné a víz szintjét. Ez ugyan sok száz évig tartó folyamat, de 1-2 fokkal melegebb klímában felgyorsulhat és akkor csak a bolygó lehütésével fordítható vissza.

Rossz hír: Az Északi Jeges-tenger jégtakarója a nyári időszakban már sokkal kisebb melegedésnél teljesen elolvadhat és csak télen fagy vissza. A tengervíz szintjét minden tized fokos melegedés emeli, és valószínüleg erősíti az Csendes óceán vízének erőteljes hőmérsékletingadozását is, amit 3-7 évenként El-Nino (átlagnál melegebb) avagy La-Nina (hűvösebb) néven illetünk. Az alacsony földrajzi szélességek légköri cirkulációjának átrendeződése mindkét esetben hónapokon át egyes térségekben aszályt, máshol ár- és belvizeket okoz.

Mindezen hatások elkerülésére nem szabad a földi átlaghömérsékletet $3{ }^{\circ} \mathrm{C}$-nál, józan előrelátással $2{ }^{\circ} \mathrm{C}$-nál magasabbra engedni. Ne feledjük, ebből már $0,8{ }^{\circ} \mathrm{C}$ megvalósult!

Jó hír: Van az üvegházhatás erősödésének olyan szintje, amelyen a koncentrációkat stabilizálva, a melegedést valószínüleg $+3{ }^{\circ} \mathrm{C}$ előtt meg lehetne állítani.

Rossz hír: Ehhez 2020-tól csökkenteni kellene a világ összes üvegházgáz kibocsátását! 


\section{Más környezeti problémák és a klímaváltozás kapcsolódásai}

Az éghajlatváltozás messze nem az egyetlen problémája a világnak, amelyről tájékozottnak kell lennünk, amikor diákjaink felvetéseire, kérdéseire reagálunk, pláne amikor magunk kezdeményezzük e kérdések megbeszélését például osztályfönöki óra keretében.

Az alábbiakban három témakört vázolunk, nem kimerítve ezzel a környezetvédelem problémáit. Először a fenntartható fejlődésre utalunk, majd a megújuló energiaforrások szükségességét és néhány újabb ismeretét vázoljuk, végül részletesebben bemutatjuk az ENSZ Milleniumi Céljait. Minden esetben utalunk a klímaváltozáshoz való kapcsolódásra.

A Fenntartható fejlődés „olyan fejlődés, amely kielégíti a jelen szükségleteit anélkül, hogy veszélyeztetné a jövő nemzedékek esélyét arra, hogy ők is kielégíthessék szükségleteiket." (Közös Jövőnk, 1988). Más megfogalmazásban (Goodland és Daly, 1996): „,.. a folytonos szociális jólét elérése anélkül, hogy az ökológiai eltartó képességet meghaladó módon növekednénk". Egy frissebb megfogalmazásban pedig ,... az emberiség jelen szükségleteinek kielégítése a környezet és a természeti erőforrások jövő generációk számára történő megőrzésével egyidejüleg." (Joint Science Academies' Statement, 2007)

Ezeket az ismert megfogalmazásokat azért tartottam szükségesnek megismételni, mert napjainkban nagyon sokféle értelemben használjuk ezt a szót, nem ritkán egyszerüen „fenntarthatóság” szinonimával, esetleg nem is gondolva rá, hogy valójában itt eredetileg az ember és az ő természeti erőforrásai közötti egyensúly fenntartásáról van szó.

Az ilyen értelmü fenntarthatóság egyik fontos mutatója a biológiai sokféleség, amely a Föld egészére nézve még mindig romló tendenciát mutat $(W W F, 2010)$. A biológiai sokféleségre gyakorolt öt legfontosabb közvetlen emberi hatás között ott van az éghajlatváltozás is, a másik négy veszélyforrás, az élőhelyek elvesztése, átalakítása és szétdarabolása; a vadon élö populációk túlzott kizsákmányolása; a környezet szinte minden elemének szennyezése és az ún. özönfajok terjedése mellett. A klímaváltozás ugyanis gyakran gyorsabb helyváltoztatásra kényszeríti a növény, de akár az állatfajokat is, mint amire azok képesek, illetve mint amiben az örök vetélkedés során az életért folyó verseny körülményei között fenn tudnak maradni.

De verseny van a gazdaságban is, ahol egy-egy vállalat vagy ország fenntarthatóságáról is beszélünk, immár nem természeti, hanem gazdasági értelemben. Ennek a másféle fenntarthatóságnak három feltétele van, a versenyképesség, az ellátásbiztonság és a környezet védelme (az élethez és a tevékenységhez alkalmas állapotban tartása). Ennek az ún. fenntarthatósági háromszögnek a sarkai gyakran más-más lépést indokolnak. Például az ellátásbiztonság érdeke Európában a minél kevesebb (import) földgáz helyett a minél több (zömmel európai) szén felhasználá- 
sa. A környezet érdeke ezzel szemben a földgáz használatát diktálja, hiszen az ebből kitermelt egységnyi energia csak fele annyi széndioxid kibocsátásával jár, mint a szénből kinyert energia esetében. A versenyképesség és a környezet érdeke is tud ütközni, például abban, hogyha egy ország erősen támogatja a környezet védelmét és kevésbé az innovációt illetve az azt megalapozó oktatást és képzést. A gazdasági (politikai) fenntarthatóság éppen azt jelenti, hogy a három feltétel között müködik valamilyen egyensúly, azaz valamilyen mértékben mindhármat figyelembe veszik. Az éghajlat változása miatti módosulások és a klímaváltozás mérséklésének világszerte fellépő (gyakran még csak erkölcsi) kötelezettsége.

Visszatérve fenntarthatóság eredeti, természeti értelmére, az ezzel manapság leggyakrabban társított kifejezés a megújuló energiaforrások, amelynek tapasztalható terjedését leggyakrabban két tényezőre, a hagyományos energiaforrások kimerülésére és a klímaváltozásra szokás visszavezetni. Pedig ezen energiaforrások terjedését számos, a hagyományos, illetve atomenergiával kapcsolatos probléma indokolja. E problémáknak az erőforrások gyors kimerülése még nem, a klímaváltozás pedig csak az egyik oka. A teljes motiváció véleményünk szerint röviden az alábbiakban foglalható össze:

- Egyre nő a hagyományos energiaforrások kitermelésének költsége, mert egyre mélyebbről, vagy más okból nehéz körülmények között lehet csak új lelöhelyeket feltárni.

- Gyakori a fizetőképesség hiánya, az eladósodás olyan országokban, amelynek pedig import energiára lenne szükség.

- Már ma is törnek ki háborúk a források érdekében, illetve elöfordul piaci zsarolás is. Elég csak a pár éve hazánkat is érintő polémiára utalni a gázellátással kapcsolatban.

- A nukleáris energia a müszaki és a politikai kockázatok (pl. terror-veszély) miatt nem bővíthető tetszés szerinti irányban. Emellett megoldandó a nukleáris szennyezés is.

- A hagyományos energiaforrások sokféle anyaggal szennyezik a környezet, amelyek egy része minden bizonnyal elsődleges okozója a globális klímaváltozásnak.

Végül, nézzük, hogy miként kapcsolódnak az ENSZ 2015-re kitüzött Millenniumi Fejlesztési Céljai $(M D G, 2000)$ a klímaváltozáshoz. E célokat az 1. táblázatban foglaltuk össze. E nyolc fö- és 18 részcél $(\mathrm{R})$ megismertetése a tanulókkal önmagában is javasolhatók, hiszen a célok plasztikussá teszik a diákok számára a világ egy részén látható elmaradás mibenlétét.

Legalább hat részcél esetében pedig egyértelmü a kapcsolat a klímaváltozással. Az éhségtől szenvedő emberek számának csökkentése (R2) és a malária terjedésének visszafordítása (R8) önmagában is nehéz, de sajnos a klímaváltozás mindkettőt korlátozza. A fenntartható fejlődés alapelveinek törvénybe iktatása (R9) segíthet 
a világ egészében korlátozni a kibocsátást, noha sok fejlődő országban a közvetlenebb degradációt kell megállítani. A megbízható ivóvízhez jutás (R10) esélyeit a globális klímaváltozás sokfelé nemcsak a csapadék csökkenésével, de a melegedés miatt a párolgás növekedésével is rontja. A nyomornegyedekben lakók számának csökkentését (R11) sem segíti a változás, hiszen például a tengerszint emelkedése egyes becslések szerint további százmilliókat kényszerít majd lakóhelyük elhagyására. Végül, ugyanez a folyamat dominálja a szigetállamok sajátos körülményeit is (R14).

1. táblázat: Az ENSZ 2015-re kitüzött Millenniumi Fejlesztési Céljai (MDG, 2000)

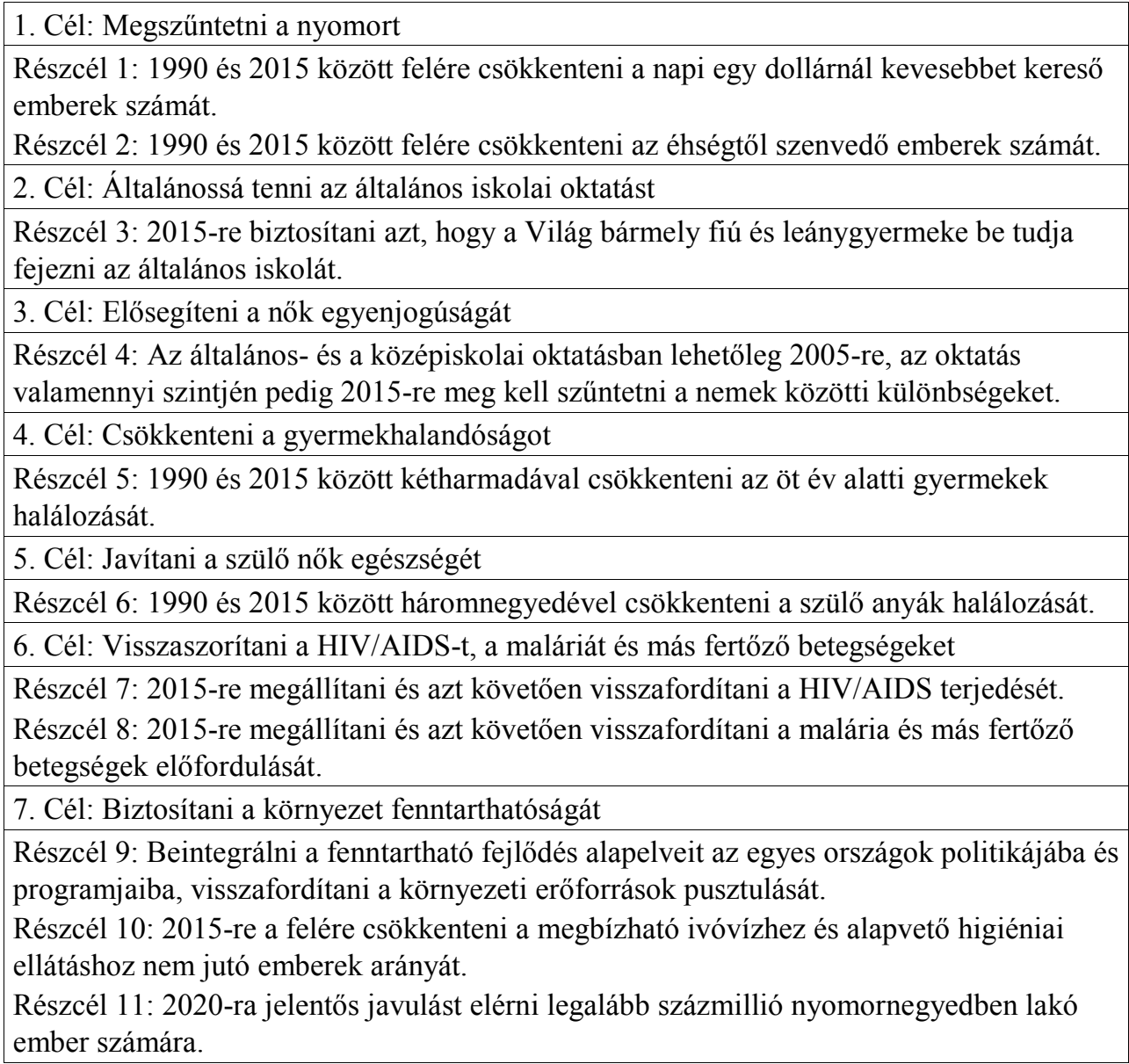




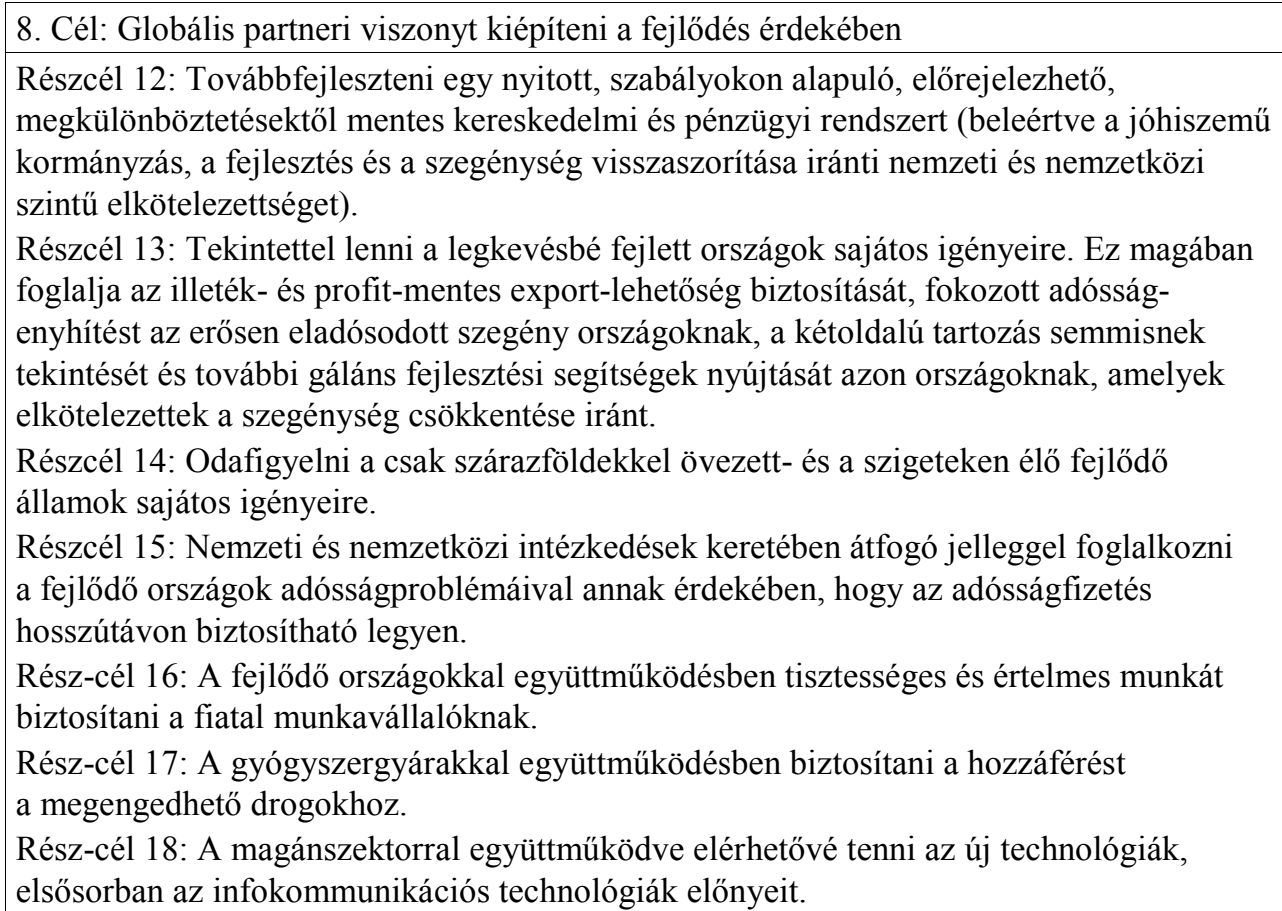

\section{Oktatás és nevelés a klímaváltozás segítségével}

E fejezetben olyan lehetőségekre mutatunk példát, amikor a klímaváltozás iránti érdeklődést használjuk fel más tárgyak oktatásában, és további nevelési feladatokat segíthetünk ezáltal.

\section{Földrajztanitás a klímaváltozáshoz kapcsolódva}

Elsőként a klímaváltozáshoz legközelebb álló tárgy, a földrajz lehetőségeit foglaljuk össze a 2. táblázatban. Ennek oszlopaiban rendre a bemutatandó jelenség szerepel, majd az azt átfogó tágabb földrajzi fejezet. Ezt követi annak jelzése, hogy a kérdéses jelenség miért fontos, végül pedig az, hogy miként kapcsolódik a klímaváltozáshoz. Gyakorlatilag a földrajz minden ágában találhatunk az éghajlatváltozáshoz kapcsolódó témaköröket. Megjegyezzük továbbá, hogy a medencehatást is tárgyalhatjuk a klímaváltozáshoz kapcsolódva (Pajtókné, 2010). 
2. táblázat: Példák a klímaváltozáshoz kapcsolható földrajzi folyamatokra és jelenségekre. (Pajtók-Tari et al., 2011)

\begin{tabular}{|c|c|c|c|}
\hline $\begin{array}{c}\text { Jelenség/ } \\
\text { törvényszerüség }\end{array}$ & $\begin{array}{l}\text { Tágabb } \\
\text { témakör }\end{array}$ & \begin{tabular}{|c|} 
A kiemelés \\
fontossága \\
\end{tabular} & $\begin{array}{c}\text { Éghajlati } \\
\text { kapcsolódás }\end{array}$ \\
\hline A felszín anyaga változik & geológia & Kőzetek aprózódása & $\begin{array}{l}\text { Extrém időjárási } \\
\text { jelenségek, } \\
\text { szélsőségek } \\
\text { fokozódása. }\end{array}$ \\
\hline $\begin{array}{l}\text { A felszín átalakul, az } \\
\text { átalakulás mértéke gyorsul }\end{array}$ & geomorfológia & $\begin{array}{l}\text { A külső erők (víz, szél, } \\
\text { hőmérséklet-változás) } \\
\text { felszínformáló munkája }\end{array}$ & $\begin{array}{l}\text { Extrém időjárási } \\
\text { jelenségek, } \\
\text { szélsőségek } \\
\text { fokozódása. }\end{array}$ \\
\hline $\begin{array}{l}\text { Talajerózió } \\
\text { Zonális és azonális talajok } \\
\text { területi átalakulása }\end{array}$ & talajföldrajz & $\begin{array}{l}\text { Talajpusztulás } \\
\text { Áradások okozta } \\
\text { talajmódosulás } \\
\text { (öntéstalajok területi } \\
\text { gyarapodása) }\end{array}$ & $\begin{array}{l}\text { Intenzív } \\
\text { esőzések } \\
\text { gyakorisága } \\
\text { fokozódik. }\end{array}$ \\
\hline $\begin{array}{l}\text { Növény-övek eltolódása; } \\
\text { egyedek kipusztulása, új } \\
\text { egyedek megjelenése }\end{array}$ & biogeográfia & Az élővilág megőrzése & $\begin{array}{l}\text { Éghajlati övek } \\
\text { eltolódása. }\end{array}$ \\
\hline $\begin{array}{l}\text { Az ökoszisztéma } \\
\text { egyensúlyának } \\
\text { felborulása; } \\
\text { A Világtenger } \\
\text { térfogatának növekedése; }\end{array}$ & hidrogeográfia & $\begin{array}{l}\text { A Világtenger melegedése, } \\
\text { térfogat-növekedés. } \\
\text { Jégtakarók, gleccserek } \\
\text { olvadása; } \\
\text { A tengerszint emelkedése. }\end{array}$ & $\begin{array}{l}\text { Globális } \\
\text { melegedés } \\
\text { Intenzív } \\
\text { esőzések } \\
\text { gyakorisága } \\
\text { fokozódik. }\end{array}$ \\
\hline $\begin{array}{l}\text { Az atmoszféra kémiai } \\
\text { össze-tételének } \\
\text { megváltozása } \\
\text { Az ózonréteg károsodása } \\
\text { Üvegházhatás fokozódása } \\
\text { Extraterresztikus sugárzás }\end{array}$ & klimatológia & $\begin{array}{l}\text { A légkör } \mathrm{CO}_{2} \text { - és más } \\
\text { káros anyag tartalmának } \\
\text { növekedése; } \\
\text { A troposzféra melegedése. } \\
\text { A bioszféra és az emberiség } \\
\text { veszélyeztetettsége. }\end{array}$ & $\begin{array}{l}\text { Globális } \\
\text { felmelegedés. }\end{array}$ \\
\hline $\begin{array}{l}\text { Népességvándorlás } \\
\text { (Migráció) }\end{array}$ & $\begin{array}{l}\text { népesség- } \\
\text { földrajz }\end{array}$ & $\begin{array}{l}\text { A népesség átrendeződése, } \\
\text { bizonyos területek } \\
\text { elnéptelenedése, korábban } \\
\text { lakatlan területek esetleges } \\
\text { benépesülése. }\end{array}$ & $\begin{array}{l}\text { Éghajlati övek } \\
\text { eltolódása, } \\
\text { elsivatagosodás, } \\
\text { tengerparti } \\
\text { területek víz alá } \\
\text { kerülése. }\end{array}$ \\
\hline
\end{tabular}




\begin{tabular}{|l|l|l|l|}
\hline \multicolumn{1}{|c|}{$\begin{array}{c}\text { Jelenség/ } \\
\text { törvényszerüség }\end{array}$} & \multicolumn{1}{|c|}{$\begin{array}{c}\text { Tágabb } \\
\text { témakör }\end{array}$} & \multicolumn{1}{c|}{$\begin{array}{c}\text { A kiemelés } \\
\text { fontossága }\end{array}$} & $\begin{array}{c}\text { Éghajlati } \\
\text { kapcsolódás }\end{array}$ \\
\hline Települések átalakulása & $\begin{array}{l}\text { település- } \\
\text { földrajz }\end{array}$ & $\begin{array}{l}\text { Települések megszünése, } \\
\text { újak létrejötte. }\end{array}$ & Mint fentebb \\
\hline $\begin{array}{l}\text { Költségvetési tényezök } \\
\text { változása }\end{array}$ & $\begin{array}{l}\text { gazdasági } \\
\text { földrajz }\end{array}$ & $\begin{array}{l}\text { Hatások elleni védekezés } \\
\text { és válaszadás költségeinek } \\
\text { emelkedése . }\end{array}$ & Mint fentebb \\
\hline $\begin{array}{l}\text { Út- és vasúthálózat, vízi } \\
\text { közlekedés útvonalainak } \\
\text { módosulása }\end{array}$ & $\begin{array}{l}\text { közlekedés- } \\
\text { földrajz }\end{array}$ & $\begin{array}{l}\text { Tavak, folyók kiszáradása, } \\
\text { újak keletkezése, } \\
\text { Közutak, vasutak építése. }\end{array}$ & Mint fentebb \\
\hline $\begin{array}{l}\text { Táplálék és ivóvízhiány } \\
\text { társadalom- } \\
\text { földrajz }\end{array}$ & $\begin{array}{l}\text { Elszegényedés, éhezés, } \\
\text { ivóvízhiány, járványok } \\
\text { kialakulása. }\end{array}$ & Mint fentebb \\
\hline $\begin{array}{l}\text { Klimatológiai és éghajlati } \\
\text { feltételek megváltozása } \\
\text { Extrém időjárási } \\
\text { jelenségek gyakoriságának } \\
\text { fokozódása } \\
\text { Új kártevök megjelenése }\end{array}$ & $\begin{array}{l}\text { mezögazdaságigi } \\
\text { földrajz }\end{array}$ & $\begin{array}{l}\text { Új, szélsőséges időjárást } \\
\text { türő fajok, haszonnövények } \\
\text { nemesítése. } \\
\text { Növény- és állatfajok } \\
\text { alkalmazkodása. } \\
\text { Védekezés szervezése. }\end{array}$ & Mint fentebb \\
\hline
\end{tabular}

\section{Példák más természettudományos tárgyak oktatására}

A földrajzhoz hasonlóan, más természettudományokban is bőven találunk lehetőséget arra, hogy az illető tárgyak fontos és érdekes jelenségeit kiemeljük, akár csokorba kötve mutassuk be, mint amik kapcsolódnak a klímaváltozáshoz. Vagy, s ezt sugallják a tantervek, egy-egy ilyen jelenséghez érkezve, utalhatunk azok éghajlati kapcsolataira. Természetesen, a diákokat érdeklő, más jelenségekre is érdemes utalnunk. (Ütöné et al., 2011).

A természettudományok oktatását közvetlenül a klímaváltozás is motiválhatja. Két példa erre a fizika és a kémia lehetőségeinek gyüjteménye a 3. és a 4. táblázatban.

3. táblázat: Példák a klímaváltozáshoz kapcsolható fizikai folyamatokra és jelenségekre. (Pajtók-Tari et al., 2011)

\begin{tabular}{|l|l|l|l|}
\hline \multicolumn{1}{|c|}{$\begin{array}{c}\text { jelenség/ } \\
\text { törvényszerüség }\end{array}$} & \multicolumn{1}{|c|}{$\begin{array}{c}\text { tágabb } \\
\text { témakör }\end{array}$} & \multicolumn{1}{c|}{$\begin{array}{c}\text { a kiemelés } \\
\text { fontossága }\end{array}$} & $\begin{array}{c}\text { éghajlati } \\
\text { kapcsolódás }\end{array}$ \\
\hline Olvadás, fagyás & $\begin{array}{l}\text { Halmazállapot- } \\
\text { változások }\end{array}$ & $\begin{array}{l}\text { Sarki jégsapkák olvadása, } \\
\text { tengerszint emelkedés }\end{array}$ & $\begin{array}{l}\text { Globális } \\
\text { felmelegedés }\end{array}$ \\
\hline $\begin{array}{l}\text { Hőmérséklet és } \\
\text { hőmérsékletváltozás }\end{array}$ & $\begin{array}{l}\text { Termikus } \\
\text { kölcsönhatás }\end{array}$ & Elsivatagosodás & $\begin{array}{l}\text { Éghajlati } \\
\text { változások }\end{array}$ \\
\hline
\end{tabular}




\begin{tabular}{|c|c|c|c|}
\hline $\begin{array}{l}\text { jelenség/ } \\
\text { törvényszerüség }\end{array}$ & $\begin{array}{l}\text { tágabb } \\
\text { témakör }\end{array}$ & $\begin{array}{l}\text { a kiemelés } \\
\text { fontossága }\end{array}$ & $\begin{array}{c}\text { éghajlati } \\
\text { kapcsolódás }\end{array}$ \\
\hline Napsugárzás & $\begin{array}{l}\text { A fény } \\
\text { kölcsönhatása } \\
\text { az anyaggal }\end{array}$ & $\begin{array}{l}\text { Ultraibolya sugárzás hatása } \\
\text { az élő szervezetekre }\end{array}$ & $\begin{array}{l}\text { Napszaki } \\
\text { változások } \\
\text { az éghajlati } \\
\text { övezetekben } \\
\end{array}$ \\
\hline $\begin{array}{l}\text { Földi légkör abszorpciója } \\
\text { a különböző hullámhosszú } \\
\text { sugárzásokra }\end{array}$ & $\begin{array}{l}\text { Elektro- } \\
\text { mágneses } \\
\text { sugárzások }\end{array}$ & Üvegházhatás & $\begin{array}{l}\text { Globális } \\
\text { felmelegedés }\end{array}$ \\
\hline $\begin{array}{l}\text { A légkör széndioxid } \\
\text { szennyezése }\end{array}$ & Az égés & Üvegházhatás & $\begin{array}{l}\text { Globális } \\
\text { felmelegedés }\end{array}$ \\
\hline $\begin{array}{l}\text { A víz rendellenes } \\
\text { viselkedése }\end{array}$ & $\begin{array}{l}\text { Hőjelenségek: } \\
\text { hőtágulás }\end{array}$ & $\begin{array}{l}\text { Víziállatok klímaváltozással } \\
\text { bekövetkező élettér } \\
\text { megváltozása }\end{array}$ & $\begin{array}{l}\text { Égövi } \\
\text { eltolódások } \\
\text { a klímaváltozá- } \\
\text { sok során }\end{array}$ \\
\hline $\begin{array}{l}\text { Áramlások légkörben, } \\
\text { óceánokban }\end{array}$ & $\begin{array}{l}\text { Hőjelenségek: } \\
\text { hőáramlás }\end{array}$ & $\begin{array}{l}\text { Áramlatok klímastabilizáló } \\
\text { hatása }\end{array}$ & $\begin{array}{l}\text { A légkörben, } \\
\text { vizekben létre- } \\
\text { jövő (meglévő) } \\
\text { áramlatok } \\
\text { helyiklíma- } \\
\text { alakító szerepe }\end{array}$ \\
\hline A Föld forgása, keringése & $\begin{array}{l}\text { Forgómozgás, } \\
\text { körmozgás }\end{array}$ & $\begin{array}{l}\text { A Föld perdületének } \\
\text { (impulzusmomentumának) } \\
\text { állandósága }\end{array}$ & $\begin{array}{l}\text { Évszakok } \\
\text { váltakozása }\end{array}$ \\
\hline Ürfelvételek & $\begin{array}{l}\text { Meteorológiai } \\
\text { müholdak }\end{array}$ & $\begin{array}{l}\text { Klímaváltozás folyamatos } \\
\text { követése }\end{array}$ & $\begin{array}{l}\text { Változó } \\
\text { klímazónák }\end{array}$ \\
\hline $\begin{array}{l}\text { Napsugárzás eredete } \\
(\mathrm{H}, \mathrm{He})\end{array}$ & Atomfizika & $\begin{array}{l}\text { Klímaváltozást meghatározó } \\
\text { tényező }\end{array}$ & $\begin{array}{l}\text { A Földre érkező } \\
\text { sugárzás } \\
\text { hatásmecha- } \\
\text { nizmusa }\end{array}$ \\
\hline $\begin{array}{l}\text { Természetes } \\
\text { radioaktivitás }\end{array}$ & $\begin{array}{l}\text { Elektro- } \\
\text { mágneses } \\
\text { sugárzások }\end{array}$ & Radioaktív sugárzások & $\begin{array}{l}\text { Föld belsejének } \\
\text { melege és } \\
\text { a radioaktivitás } \\
\text { kapcsolata }\end{array}$ \\
\hline
\end{tabular}


4. táblázat: Példák a klímaváltozáshoz kapcsolható kémiai folyamatokra és jelenségekre. (Pajtók-Tari et al., 2011)

\begin{tabular}{|l|l|l|l|}
\hline \multicolumn{1}{|c|}{$\begin{array}{c}\text { jelenség/ } \\
\text { törvényszerüség }\end{array}$} & \multicolumn{1}{|c|}{ tágabb témakör } & \multicolumn{1}{|c|}{$\begin{array}{c}\text { a kiemelés } \\
\text { fontossága }\end{array}$} & éghajlati kapcsolódás \\
\hline A levegö összetétele & $\begin{array}{l}\text { Környezetünk } \\
\text { anyagai/ } \\
\text { Szervetlen kémia }\end{array}$ & $\begin{array}{l}\text { Életterünk } \\
\text { megismerése }\end{array}$ & $\begin{array}{l}\text { Üvegház-gázok, } \\
\text { hatásuk }\end{array}$ \\
\hline fotokémiai reakciók & $\begin{array}{l}\text { Szervetlen kémia } \\
\text { (oxigén) }\end{array}$ & $\begin{array}{l}\text { A légkörben } \\
\text { lejátszódó } \\
\text { folyamatok }\end{array}$ & $\begin{array}{l}\text { ózonképzödés } \\
\text { és bomlás }\end{array}$ \\
\hline $\begin{array}{l}\text { Légszennyezö szilárd } \\
\text { anyagok }\end{array}$ & $\begin{array}{l}\text { Környezetünk } \\
\text { anyagai }\end{array}$ & $\begin{array}{l}\text { környezet- } \\
\text { szennyezés }\end{array}$ & $\begin{array}{l}\text { Szállópor, száraz, } \\
\text { nedves ülepedés } \\
\text { hatása a környezetre } \\
\text { Ózon-bontás }\end{array}$ \\
\hline Légszennyezö gázok & $\begin{array}{l}\text { Környezetünk } \\
\text { anyagai }\end{array}$ & $\begin{array}{l}\text { környezet- } \\
\text { szennyezés }\end{array}$ & $\begin{array}{l}\text { száraz, nedves } \\
\text { kiülepedés élö } \\
\text { környezetre } \\
\text { gyakorolt hatása } \\
\text { Ózon-bontás }\end{array}$ \\
\hline Elemek körforgása & Környezeti kémia & $\begin{array}{l}\text { A megújuló } \\
\text { környezet }\end{array}$ & $\begin{array}{l}\text { Csapadékvíz-minőség } \\
\text { Talajerö-pótlás }\end{array}$ \\
\hline
\end{tabular}

\section{Ismerkedés az időjárási szélsőségekkel}

Az éghajlatváltozással gyakran párba állítjuk az időjárási szélsőségek alakulását. Bár ez nem ennyire egyértelmü (bizonyos fajtákra igaz, másokra nem, még több szélsőség-fajtára nem egyértelmü), fontos nevelési cél, hogy diákjaink tisztában legyenek az őket körülvevő élő és élettelen környezet valós veszélyeivel, és tájékozottak legyenek az ilyen események előfordulása idején követendő-, illetve kerülendő magatartásról. Ez azért is fontos, mert ezek a kockázatok gyakran később alakultak ki (később tudatosultak a társadalomban) mint ahogy az előző generációk iskolába jártak. Gyakorta halljuk, hogy egy-egy katasztrófa idején egy-egy gyerek hívta fel a figyelmet a tennivalókra (függetlenül attól, hogy hittek-e neki a felnőttek).

A légkörben az időjárási katasztrófák mindegyike valamilyen mozgó légköri objektumhoz kapcsolódik. Ezek lehetnek több ezer kilométeresek, mint a mérsékeltövi ciklonok és az anticiklonok (ezekről még tanulunk az iskolában), pár száz kilométeresek, mint a hideg- és melegfrontok és a kezdődő trópusi ciklonok (még ezekről is), de ugyanígy néhány kilométeresek, sőt ennél is kisebbek (pl. a tornádók, amikre már általában nem jut idő a földrajz órákon). 
Maguk az objektumok még nem veszélyforrások, ám hordozhatnak olyan, a légkör állapotával kapcsolatos kockázatokat, mint (csökkenő tér-idö léptékben) az aszály, a tartósan erős fagyok, a hőhullámok, a késő tavaszi (kora őszi) fagyok, a konvektív szélerősödés, a tartós esőzés, a hirtelen hóolvadás, az áradás, a heves csapadékhullás, a jégeső, stb.

A legtöbb jelenség elörejelzésére legalább pár óra időelőnnyel ma már megbízható, azonban a károk közvetlen elhárítására csekély a lehetőség. Világszerte a jégeső-elhárítás, a felhö-oszlatás és csapadékkeltés terén beszélhetünk hosszabbrövidebb ideig sikeres operatív kipróbálásról. A jégeső-elhárítás például jelenleg is folyik Magyarországon.

A természeti katasztrófák mintegy $90 \%$-a egy adott időszakban meteorológiai eredetü volt! Csak a vulkánkitörések és a földrengések nincsenek kapcsolatban az időjárással. Hiszen, még az árvizek előidézője is valamilyen hosszabban kumulálódó eltérés a csapadékban vagy a hirtelen hóolvadás a magas hegységekben.

A meteorológiai szélsőségek nemcsak önmagukban jelentenek kockázatot, hanem olyankor is, amikor más eredetủ katasztrófa-helyzet fenyeget. Sőt, ilyenkor az átlagos állapot elörejelzése is meghatározó jelentőségü lehet. Például, ipari szenynyeződés levegőbe kerülésekor, vagy a nyári fotokémiai vagy téli, hagyományos szmog-helyzeteknél a szél iránya, sebessége, a légrétegződés stabil (a vertikális elkeveredést gátló) volta fokozza veszélyt. Még nyilvánvalóbb, hogy árvízi veszélyeztetettségnél akár a végleges vízállást, akár a védelmi munka körülményeit befolyásoló tényezőként a csapadékhullás illetve a napos idő (fokozott párolgás, könnyebb védekezés) is szerepet játszik.

Elövigyázatossági intézkedések. A lehetséges intézkedések jogi hátterét az 1996. évi XXXVII. Törvény (,,a polgári védelemről”) és az 1999. évi LXXIV. Törvény (,a katasztrófák elleni védekezés irányításáról, szervezetéről és a veszélyes anyagokkal kapcsolatos súlyos balesetek elleni védekezésról") szolgáltatja. Mivel azonban mindkettő eléggé régi, $\mathrm{s}$ azóta számos újabb felismerés született, amelyek beépítése a szerző tudomása szerint is folyamatban van, ehelyütt inkább a zürichi Szövetségi Műszaki Főiskola „Természeti Kockázatok Kezelése” címü, ott egyenesen mesteri szinten megkezdett képzéséböl (ETH, 2009) válogattuk.

A természeti csapások kockázatát csökkentő intézkedések többek között az alábbiak lehetnek: Folyószabályozás az árvizek mérséklése érdekében, A kikötők és hidak megerősítése, Lejtőszög módosítás, víz-vezetö árkok, -terelök, Fokozott erdősítés a talajmegkötés, a lefolyás lassítása, a földcsuszamlási kockázat mérséklése és a szélerózió mérséklése érdekében.

A fenti gondolatokat jó lenne viszontlátni minél több földrajzkönyvben. Néhány esetben (pl. Arday et al., 2003, 2004; Probáld és Ütőné Visi, 2010) legalább az időjárás mint veszélyforrás szerepel. Néhány gyakorló feladat példája látható erről a FÖLDRAJZ nEtSZKÖZKÉSZLET internetes tudástárban is (Pajtókné Tari, 2006, 2008) 


\section{Energia-takarékosságra nevelés}

A klímaváltozás témakörében tartott előadásaim slágere az ún. Kaya egyenlet (Ehrlich és Holdren, 1971), amely szerint a Világ széndioxid kibocsátása négy tényezö szorzataként áll elö. E négy tényező a világ népessége (népesség: fö), az egy före jutó nemzeti össztermék ( $G D P /$ népesség: USD/fö), az egységnyi termék előallításához szükséges energia (TPES/GDP: MWh/USD), más néven „energia-hatékonyság” és az egységnyi energia elöállításához szükséges széndioxid ( $\mathrm{CO}_{2} / \mathrm{TPES}$ : Gt/MWh), a „karbon-intenzitás”.

Az utóbbi két tényező az 1970-es évek óta fokozatosan javul, azaz csökken a javak energiaigénye (nő az energiahatékonyság) és a karbon-intenzitása. E két hatás együtt 2005-re 40 százalékkal csökkentette a kibocsátás harmadik és negyedik tényezőjének a szorzatát.

Csakhogy, ezzel egy idöben a Föld népessége és a megtermelt jövedelem (egyenetlen eloszlásban) ennél gyorsabban nőtt. A népesség 75\%-kal, az egy före eső össztermék pedig $80 \%$-kal nőtt. A négy tényező együttes hatására a $\mathrm{CO}_{2}$-kibocsátás 35 év alatt megduplázódott.

Ezt a nagyon erős növekedési ütemet kell valahogyan megállítani! Vegyük sorra, hogy a szorzat négy tényezőjében milyenek a kibocsátás-csökkentés kilátásai.

A népesség számának alakulásával kapcsolatban nem lehetnek illúzióink, az továbbra is erősen növekedni fog. Ha nem így lenne, az igen nagy problémára utalna, pl. járványszerü fertőző betegségekre, tömegeket érintő éhínségre, vagy kiterjedt háborúkra. Talán arra van esély, hogy a növekedés üteme valamelyest csökkenjen.

Ugyancsak nem kívánatos az egy före jutó össztermék csökkenése, habár ez számszaki értelemben mintegy „magától” is végbemehet. Hiszen a népesség a szegényebb országokban növekszik erőteljesen. Tehát, ha a világ népességének növekedési üteme meghaladja a bruttó össztermék növekedési ütemét, akkor a szorzat második tényezője csökken.

Igazi mérséklési lehetőséget a harmadik és a negyedik tényező adhat. Kedvező változás, hogy egységnyi terméket egyre kevesebb energiával tudnánk előállítani. E stabil tendencia a 80-as évektől gyorsuló ütemü, egyaránt tartalmazva a termelés és a fogyasztás takarékosságát.

A másik lehetőség, ha a felhasznált energia kevesebb $\mathrm{CO}_{2}$-kibocsátással jár. Ebben a körben a lehetőségek három csoportját különböztetjük meg:

a) A fosszilis alapú energiák kategóriáján belüli csökkentés, mivel a földgázból ugyanannyi energiát kevesebb $\mathrm{CO}_{2}$-felszabadulás mellett meg lehet termelni, mint kőolajból, még inkább, mint szénből.

b) A megújuló energiák preferálása.

c) A kibocsátott szén-dioxid számottevő hányadának kivonása a légkörből. 
Bolygónk klímájának eltolásáért a gazdálkodó szervezetek mellett bizony mi magunk is felelősek vagyunk. A kibocsátás 30-40\%-át az otthonainkban és a közlekedés során mi magunk okozzuk. Az 5. táblázatban megmutatjuk, hogy milyen lehetőségeink vannak az energiatakarékosságra. Az élet sok más gondja mellett immár erre is oda kell figyelnünk! Ugyanakkor, ezek a lépések azonnal, vagy egy beruházás megtérülése után pénzbeli nyereséget hoznak.

\section{5. táblázat: Gyakorlati tanácsok az energiával való takarékosságra}

\begin{tabular}{|c|c|c|}
\hline $\begin{array}{l}\text { Tekerje lejjebb a fütést! } \\
\text { Cserélje le szimpla üvegü } \\
\text { ablakait dupla üvegü } \\
\text { ablakokra! } \\
\text { Rövid ideig szellőztessen, } \\
\text { nehogy a meleg kiszökjön } \\
\text { az ablakon! } \\
\text { Hőszigetelje megfelelően } \\
\text { otthonát! } \\
\text { Programozza be a } \\
\text { termosztátot! } \\
\text { Kapcsolja ki a villanyt! } \\
\text { Húzza ki a csatlakozóból } \\
\text { a mobiltelefon-töltőt, } \\
\text { ha már feltöltötte! } \\
\text { Ne hagyja készenléti } \\
\text { állapotban az elektromos } \\
\text { készülékeket! } \\
\text { Vegyen energiatakarékos } \\
\text { égőket! }\end{array}$ & $\begin{array}{l}\text { Használjon ventillátort } \\
\text { a légkondicionáló helyett! } \\
\text { Fedje le edényeit fózés } \\
\text { közben! } \\
\text { Zuhanyozzon fürdés helyett! } \\
\text { Zárja el a csapot! } \\
\text { Az üres üvegeket vigye } \\
\text { vissza, a papírt, a műanyagot } \\
\text { és a fémet gyüjtse, majd } \\
\text { dobja a tározókba } \\
\text { elkülönítve! } \\
\text { Válasszon minél kevesebb } \\
\text { csomagolóanyagba } \\
\text { csomagolt terméket, és ha } \\
\text { lehet, utántöltő termékeket! } \\
\text { Vásároljon okosan! }\end{array}$ & $\begin{array}{l}\text { Ha autóval jár munkába, } \\
\text { próbálkozzon más } \\
\text { alternatívákkal is! } \\
\text { Kerékpározzon, gyalogoljon, } \\
\text { vagy használja } \\
\text { a tömegközlekedést! } \\
\text { Kerülje a rövid autóutakat! } \\
\text { Haladjon az üzemanyagot } \\
\text { és nem az időt optimalizáló } \\
\text { sebességgel! } \\
\text { Ha teheti, az autóját mossa } \\
\text { kézzel! } \\
\text { Gondoskodjon a megfelelö } \\
\text { kerék-nyomásról! Ne hagyja } \\
\text { fenn autóján az üres } \\
\text { tetőcsomagtartót! } \\
\text { A repülés és a személyautó } \\
\text { helyett is keressen más } \\
\text { alternatívát! }\end{array}$ \\
\hline
\end{tabular}

\section{A kulcskompetenciák fejlesztési lehetöségei}

A NAT (2007) - Kerettantervek az iskolai nevelés-oktatás alapvető céljaként elöírják a kulcskompetenciák fejlesztését (Ütöné, 2009). A Nemzeti Alaptantervben megjelenő kulcskompetenciák alapját a Recommendation..., (2006) dokumentum képezi. Mind a kilenc kulcskompetenciához megadtunk lehetséges módokat arra, hogy a klímaváltozással kapcsolatos módokon fejlessze a tanár a kulcskompetenciákat. Így már a második olyan nevelési alkalmazásra derült fény, amelynek célja nem az eredeti-, azaz magának a klímaváltozásnak a megismerése, hanem egy vagy több más természetủ nevelési cél (6. táblázat). 
6. táblázat: Éghajlat, klímaváltozás az egyes kulcskompetenciák segítésére

\begin{tabular}{|l|l|}
\hline \multicolumn{1}{|c|}{ Kulcskompetencia } & \multicolumn{1}{|c|}{ Milyen éghajlati kapcsolódással fejleszthetö? } \\
\hline Anyanyelvi kommunikáció & $\begin{array}{l}\text { Az éghajlat, a hatások és a válaszadás új szavainak, } \\
\text { kifejezésének a megtanulása. }\end{array}$ \\
\hline Idegen nyelvi kommunikáció & $\begin{array}{l}\text { A klímaváltozásról a világban is zajló éles viták } \\
\text { megértése, mint motiváció. }\end{array}$ \\
\hline Matematikai kompetencia & $\begin{array}{l}\text { A klímaváltozás bonyolult számításainak és a jelenség } \\
\text { fontosságának a megértése. }\end{array}$ \\
\hline $\begin{array}{l}\text { Természettudományos } \\
\text { kompetencia }\end{array}$ & $\begin{array}{l}\text { A klímaváltozás számtalan lehetőséget kínál } \\
\text { a természettudományos kompetenciák fejlesztésére } \\
\text { (ld. 2-3-4. táblázat) }\end{array}$ \\
\hline Digitális kompetencia & $\begin{array}{l}\text { Az Internet általános használatán, mint illusztráción túl, } \\
\text { minden éghajlati modell számítás komputeren fut. }\end{array}$ \\
\hline Hatékony önálló tanulás & $\begin{array}{l}\text { Ha a klímaváltozás önálló tanulása kitűzhető célként, } \\
\text { akkor erre a gazdag nyomtatott és internetes irodalom } \\
\text { jó lehetöséget kínál. }\end{array}$ \\
\hline $\begin{array}{l}\text { Szociális és állampolgári } \\
\text { kompetencia }\end{array}$ & $\begin{array}{l}\text { Az időjárási katasztrófák idején tapasztalható } \\
\text { összefogás az együttmüködés hősies, jó példái. }\end{array}$ \\
\hline $\begin{array}{l}\text { Kezdeményezőképesség } \\
\text { és vállalkozói kompetencia }\end{array}$ & $\begin{array}{l}\text { A megújuló energiák használatát és az alacsony } \\
\text { széndioxid felhasználását elösegítő iparágak a legjobb } \\
\text { példák lehetnek a sikeres vállalkozásra. }\end{array}$ \\
\hline $\begin{array}{l}\text { Esztétika-müvészeti tudatosság } \\
\text { és kifejezőképesség }\end{array}$ & $\begin{array}{l}\text { A természet maga kínálja az esztétikai érzék fejlesztését } \\
\text { számos optikai jelenségen keresztül. }\end{array}$ \\
\hline
\end{tabular}

\section{Epilógus}

Közoktatásunk átalakulás elött áll. Jó lenne a fenti lehetőségeket mindkét vonatkozásban beépíteni az oktatásba. A Nemzeti Köznevelésröl Szóló Törvény Koncepciója (2011. augusztus 31-én elfogadott) azonban erre nem tartalmaz utalást. A koncepcióban az „éghajlat (klíma)” szó egyáltalán nem szerepel. A „környezet” - a szó természetföldrajzi értelmében - három helyen kerül említésre. Egyrészt az érettségi elöfeltételeként szabandó 50 órás közösségi aktivitásnak az ilyen tevékenység is lehet a tartalma, másrészt, a nevelési terv tartalmi elemei között utolsó, „r”-edik helyen így szerepel: „egészségfejlesztési és környezeti nevelési elvek”. Végül, a pedagógusok minősítési szempontjainak egyike: „A fejlesztésekben való részvétel, új módszerek és szempontok (pl. környezettudatosság) alkalmazása, problémamegoldás."

Kívánom mindnyájunknak, hogy a törvény végrehajtása során, például a NAT újragondolásakor, ennél egyértelmübb szerephez jussanak a környezet és a klíma- 
változás kérdései. Ha ez megvalósul, akkor talán a fenti gondolatok is alkalmazásra találhatnak.

\section{Irodalom}

Arday István, Rózsa Endre, Ütőné Visi Judit (2003, 2011): Földrajz I. Földrajz a középiskolák számára. Müszaki Kiadó, Budapest.

Arday István, Rózsa Endre, Ütőné Visi Judit (2004, 2011): Földrajz II. Földrajz a középiskolák számára. Müszaki Kiadó, Budapest.

Broecker, W. S. (1991): The great conveyor. Oceanography, Nr. 4., 79-89.

Ehrlich, P. R., Holdren, J. P. (1971): Impact of Population Growth. Science, Nr. 171 (3977), 1212-4, 1217.

ETH, 2009: Master of Advanced Studies in "Natural Hazards Management" http://www.ibk.ethz.ch/fa/haz/index letöltve: 2009. okt. 22.

Goodland, R., Daly, H. (1996): Environmental Sustainability: Universal and Non-negotiable. Ecological Applications, Vol. 4. Nr. 6. 1002-1017.

IPCC (2007): Climate Change (2007): The Physical Science Basis. Contribution of Working Group I to the Fourth Assessment Report of the Intergovernmental Panel on Climate Change, 2007 (Solomon, S., D. Qin, M. Manning, Z. Chen, M. Marquis, K. B. Averyt, M. Tignor, H. L. Miller, eds.) Cambridge University Press, Cambridge UK \& New York NY, USA.

Joint Science Academies' Statement (2007): Climate Change Adaptation and the Transition to a Low Carbon Society. Magyarul: Tudományos Akadémiák közös állásfoglalása: Alkalmazkodás a klímaváltozáshoz, átalakulás szénkímélő társadalommá. Magyar Tudomány, 2008. évi 8. sz. 1141 o. http://www.matud.iif.hu/08sze/11.html letöltve: 2009. okt. 22.

Közös Jövőnk (1988): Közös Jövőnk. A Fenntartható Fejlödés Bizottsága Jelentése. Mezögazdasági Kiadó, Budapest.

MDG (2000): Millenium Development Goals. http://www.un.org/millenniumgoals/ letöltve: 2011. okt. 11.

NAT (2007): A Kormány 202/2007. (VII. 31.) rendelete a Nemzeti alaptanterv kiadásáról, bevezetéséről és alkalmazásáról szóló 243/2003. (XII. 17.) Korm. rendelet módosításáról.

Nemzeti Köznevelésröl Szóló Törvény Koncepciója (2011): Nemzeti Erőforrás Minisztérium

Pajtókné Tari Ilona (2006): Földrajztanítás az információs társadalomban. nEtSZKÖZKÉSZLET - a földrajztanár elektronikus eszközkészlete. Iskolakultúra, 4. sz. 93-101.

Pajtókné Tari Ilona (2008): Digitális tudástárak földrajzi tartalmú oldalainak értékelése a földrajztanítás szemszögéből I. Learning Resource Exchange (LRE). Földrajzi Közlemények, 2008. 132. 1.63-69.

Pajtókné Tari Ilona (2010): A medence-jelleg okozta éghajlati és vízrajzi sajátosságok alakulása globális klímaváltozási térképek alapján. In: Kertész Ádám és mtsai (szerk.): 4. Magyar Tájökológiai Konferencia Kerekegyháza, 2010. május 13-15, 209-216. 
Pajtók-Tari Ilona, Vida József, Murányi Zoltán, Pénzes-Kónya Erika, Mika János (2011): Moments of school subjects promoted by climate change. ATEE 35, Budapest. (in press)

Probáld Ferenc, Ütőné Visi Judit (2010): Földrajz 10. Regionális Földrajz, Nemzeti Tankönyvkiadó, Budapest.

Recommendation 2006: Recommendation of the European Parliament and of the Council of 18 December 2006 on Key Competences for Lifelong Learning (2006/962/EC)

Schwartz, P., Randall, D. (2003): An Abrupt Climate Change Scenario and Its Implications for US National Security. http://www.grist.org/pdf/AbruptClimateChange2003.pdf letöltve: 2005. április 25.

Ütő-Visi Judit, Pajtók-Tari Ilona, Kürti Lívia (2011): Climatic challenges educated for perspetive teachers of geography In: Proceedings of University of West Hungary Savaria Campus Natural Sciences. Szombathely 211-215.

Ütőné Visi Judit (2009): A földrajzoktatás tartalmi, szerkezeti átalakulása, In: Pajtókné Tari Ilona (szerk.): Acta Academiae Pedagogicae Agriensis, nova series tom XXXVI, sectio geographiae, Eger, 31-48.

Wood, R. A., Vellinga, P., Thorpe, R. (2003): Global Warming and THC stability. Phil. Trans Roy. Soc. A, 361, 1961-1976.

WWF, 2010: Living Planet Report 2010. Geneva.

http://wwf.panda.org/about_our_earth/all_publications/living_planet_report/ letöltve: 2011. szept. 11. 